\section{To live or not to live near a farm?}

\author{
Katja Radon
}

One public environmental concern arising in the USA and Europe during the last decades is the increasing amount of 'confined animal feeding operations' or CAFOs. They are important for rural communities and the farming industry in order to produce meat more efficiently. But they might have a negative side effect: their unpleasant smell might hinder neighbours to dry the laundry outside the house or simply might reduce the joy of having a cup of coffee in the garden. Furthermore, they might have negative effects, especially on respiratory health-especially asthma-like symptoms and chronic bronchitis-as it is known from studies focusing on the farmers and farm workers. ${ }^{1}$ Endotoxin seems to be one of the main 'bad boys' in this setting. However, there is also considerable evidence showing that exposure to endotoxins might protect from respiratory allergies and asthma. ${ }^{2}$

Up to now, a small number of studies have been carried out - especially in the USAfocusing on the association between environmental exposure to CAFOs and health of their neighbours. ${ }^{3-7}$ These studies consistently indicated an association between environmental exposure and respiratory symptoms indicative of asthma. Recent studies from Europe, where CAFOs are usually built closer to the community, confirmed these findings. ${ }^{8-10}$

Given this situation, the results of the study presented by Smits and colleagues are interesting - and puzzling. ${ }^{11}$ The authors used general practitioner data from almost 100000 electronic medical records in a rural Dutch area to assess the association between exposure to CAFOs and respiratory diagnosis. Children and adults were included in their huge data set. Exposure was based on information about distance to nearest farm, number of farms within $500 \mathrm{~m}$ and $1000 \mathrm{~m}$ and modelled PM10 (particulate matter smaller than 10 micrometers) emissions from these farms. In addition, a case-control study was conducted. In this subpopulation, potential confounders were assessed and indoor endotoxin exposure was measured. Instead of the hypothesised adverse effect, Smit and colleagues found an inverse association between

Correspondence to Dr Katja Radon, Occupational and Environmental Epidemiology \& Net Teaching Unit, Institute and Outpatient Clinic for Occupational, Social and Environmental Medicine, University Hospital Munich (LMU), Ziemssenstr. 1, Munich D-80336, Germany; sekretariat-radon@med.Imu.de exposure to animal houses in the home environment and asthma, allergic rhinitis and chronic obstructive pulmonary disease (COPD) - independent of study design and measure of exposure. Furthermore, indoor endotoxin exposure was unrelated to the environmental conditions.

What might be the reason for this surprising result? Besides the general epidemiologic concerns-different designs might produce different results and register information might be less valid and therefore, results may be biased-two additional aspects might be considered:

In the European study mentioned earlier, the association between exposure and outcome was non-linear and the increased risk was confined to those participants who had more than 12 CAFOs within $500 \mathrm{~m}$ around their home. ${ }^{8}{ }^{9}$ Given that Smit and colleagues $^{11}$ only assumed a linear association between exposure and outcome, such a non-linear association cannot be ruled out. The reason that they did not consider such a non-linear association might be the fact that their number of neighbouring animal farms was considerably lower (mean 1.6 farms for adults, 1.7 for children) than in the German study (median 3 for adults). ${ }^{8} 911$

Furthermore, the study population of Smit et $a l^{11}$ included subjects who were raised on a farm. In the results of their case-control study, it can be seen that those with higher environmental exposures were also more likely to being raised on a farm. Therefore, effect modification by farm childhood and pet ownership might be one reason for the observed inverse association as it has been shown that primarily early life exposure to farm environments protects from allergy and atopic asthma. ${ }^{2}$

Taken together, the study by Smit and colleagues does not preclude that adverse effects of CAFOs on respiratory health exist. As always, timing and level of exposure might be the clue for the fact that their findings differ from existing evidence. One aspect that is also worthwhile mentioning as it is a general tendency in research: it is obvious that authors like to have the freedom to analyse results without using previous reports as an example. Nevertheless, I would like to encourage the presentation of analyses using similar approaches as those published before perhaps as an on-line supplement. Otherwise, heterogeneity between studies might be so large that the pooling of the results in meta-analyses is not feasible at all. Some recent systematic reviews in our field are evidence of this problems. ${ }^{12} 13$

Competing interests None.

Provenance and peer review Commissioned; internally peer reviewed.

To cite Radon K. Occup Environ Med 2014;71:79.

Received 10 September 2013

Revised 25 September 2013

Accepted 9 October 2013

Published Online First 8 November 2013

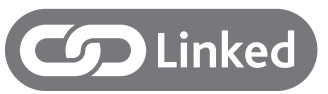

http://dx.doi.org/10.1136/oemed-2013-101485

Occup Environ Med 2014;71:79.

doi:10.1136/oemed-2013-101790

\section{REFERENCES}

1 Von Essen S, Moore G, Gibbs S, et al. Respiratory issues in beef and pork production: recommendations from an expert panel. J Agromedicine 2010:15:216-25.

2 von Mutius E, Radon K. Living on a farm: impact on asthma induction and clinical course. Immunol Allergy Clin North Am 2008;28:631-47, ix-x.

3 Karr C. Children's environmental health in agricultural settings. J Agromedicine 2012:17:127-39.

4 Kilburn $\mathrm{KH}$. Human impairment from living near confined animal (hog) feeding operations. J Environ Public Health 2012;2012:565690.

5 Mirabelli MC, Wing S, Marshall SW, et al. Asthma symptoms among adolescents who attend public schools that are located near confined swine feeding operations. Pediatrics 2006;118:e66-75.

6 Schinasi L, Horton RA, Guidry VT, et al. Air pollution, lung function, and physical symptoms in communities near concentrated Swine feeding operations. Epidemiology 2011;22:208-15.

7 Pavilonis BT, Sanderson WT, Merchant JA. Relative exposure to swine animal feeding operations and childhood asthma prevalence in an agricultural cohort. Environ Res 2013;122:74-80.

8 Radon K, Schulze A, Ehrenstein V, et al. Environmental exposure to confined animal feeding operations and respiratory health of neighboring residents. Epidemiology 2007;18:300-8.

9 Haas Y, Bisdorff B, Radon K. Respiratory health in neighboring residents of confined animal feeding operations: a longitudinal study. Ann Agric Environ Med 2013 (in press).

10 Hoopmann M, Hehl O, Neisel F, et al. [Associations between bioaerosols coming from livestock facilities and asthmatic symptoms in children]. Gesundheitswesen 2006:68:575-84.

11 Smit LA, Hooiveld M, Van der Sman-de Beer F, et al. Air pollution from livestock farms, and asthma, allergic rhinitis and COPD among neighbouring residents. Occup Environ Med 2014;71:134-40.

12 Gascon M, Morales E, Sunyer J, et al. Effects of persistent organic pollutants on the developing respiratory and immune systems: a systematic review. Environ Int 2013;52:51-65.

13 Hoven $\mathrm{H}$, Siegrist J. Work characteristics, socioeconomic position and health: a systematic review of mediation and moderation effects in prospective studies. Occup Environ Med 2013;70:663-9. 


\section{To live or not to live near a farm?}

Katja Radon

Occup Environ Med 2014 71: 79 originally published online November 8, 2013

doi: 10.1136/oemed-2013-101790

Updated information and services can be found at:

http://oem.bmj.com/content/71/2/79

\section{These include:}

References This article cites 12 articles, 3 of which you can access for free at: http://oem.bmj.com/content/71/2/79\#BIBL

Email alerting service

Receive free email alerts when new articles cite this article. Sign up in the box at the top right corner of the online article.

\section{Notes}

To request permissions go to:

http://group.bmj.com/group/rights-licensing/permissions

To order reprints go to:

http://journals.bmj.com/cgi/reprintform

To subscribe to BMJ go to:

http://group.bmj.com/subscribe/ 